\author{
Dr. sc. Matija Miloš, poslijedoktorand ${ }^{1}$ \\ Pravni fakultet Sveučilišta u Rijeci \\ Valentino Kuzelj, student ${ }^{2}$ \\ Pravni fakultet Sveučilišta u Zagrebu
}

\title{
OSTVARENJE I ZAŠTITA USTAVNOG IDEALA POREZNE PRAVEDNOSTI U SVJETLU ZAHTJEVA SOCIJALNE DRŽAVE
}

\author{
$U D K: 336.22$ \\ $364 / 365$ \\ DOI: $10.31141 / z r p f s .2021 .58 .142 .1101$ \\ Izvorni znanstveni rad \\ Primljeno: 01. 06.2021.
}

\begin{abstract}
U ovom se radu preispituje pojednostavljeno prihvaćeno i ne-preispitano razlikovanje između ustavnog koncepta socijalne države, socijalnih prava te poreznog sustava. Ono svoj praktičan učinak nalazi u djelovanju Ustavnog suda Republike Hrvatske, koji zbog jaza koji nalazi između tih kategorija propušta adekvatno tumačiti i štititi koncept socijalne države u nadzoru ustavnosti poreznog zakonodavstva. Krajnji je rezultat takvog djelovanja stvaranje prostora pretjeranog ustavnosudskog samoograničenja. Nasuprot strahu od sudskog aktivizma, koji se predstavlja kao jedina alternativa opetovanom pozivanju na doktrinu političkih pitanja, ističe se kako socijalnu državu treba tumačiti kao prožimajuću smjernicu tumačenju poreznog sustava ne bi li se ostvario značaj koji sadrži kao sastavnica hrvatskog ustavnog identiteta. Takvo povezivanje socijalne države s konkretnijim porezno-pravnim kategorijama ne mora dovesti do politički hiperaktivnog Suda, sve dok se on pri definiranju granica vlastitog djelovanja, umjesto ustrajanja na ograničenosti tumačenih načela, usredotočuje poglavito na slabosti i posljedice modusa svojeg odlučivanja.
\end{abstract}

Ključne riječi: socijalna država, socijalna prava, ustavna načela oporezivanja, porezna pravednost, Ustavni sud Republike Hrvatske

\section{UVOD}

„Ustavni sud definira socijalnu državu“, 3 ističe Rodin u naslovu rada kojim se problematizira djelovanje Ustavnog suda Republike Hrvatske (u nastavku: USRH)

1 Dr. sc. Matija Miloš, poslijedoktorand Pravnog fakulteta Sveučilišta u Rijeci, e-mail: mmilos@ pravri.hr, ORCID: https://orcid.org/0000-0002-3839-0273

2 Valentino Kuzelj, student Pravnog fakulteta Sveučilišta u Zagrebu, e-mail: valentino.kuzelj01@ gmail.com, ORCID: https://orcid.org/0000-0003-3028-8562

3 Rodin S., Ustavni sud definira socijalnu državu, Revija za socijalnu politiku, sv. 5, br. 2, 1998. , str. 111-118. 
naspram socio-ekonomskih kategorija hrvatskog Ustava ${ }^{4}$ (u nastavku: URH), tvrdeći da, iako hrvatsko ustavno sudište nema ovlasti stvarati nova socijalna subjektivna prava, mora konkretizacijom ustavnog koncepta socijalne države određivati granice zakonodavčeva djelovanja. ${ }^{5}$ Posebno, međutim, upozorava kako USRH nije forum na kojem se može provoditi politički proces kojim bi se, u definiranju sadržaja socijalne države, uzelo u obzir suprotstavljene interese i stavove. ${ }^{6}$ To, dakako, ne znači da djelovanje USRH nije politički relevantno, već da nije sasvim usporedivo s načinom rada i ovlastima zakonodavca.

Ono što se ističe spornim jest pitanje kako bi točno USRH trebao definirati socijalnu državu, po čemu se ta zadaća razlikuje od „stvaranja novih prava“ te gdje bi i kako u razmatranju socijalne države trebao povući svoje granice. U ovom radu nastoji se doprinijeti raspravi o toj problematici kroz povezivanje dvaju tema iz ranije spomenutog rada. Prvo, proučava se problem načelne odvojenosti socijalne države, socijalnih prava i, posebno, poreznog sustava. Drugo, nastoji se osvrnuti i na pitanje ograničenosti USRH pri razmatranju suprotstavljenih političkih interesa u konkretizaciji socijalne države. Važnost otvaranja navedenih tema apostrofirana je time što je, kao što će biti prikazano infra, hrvatska ustavnosudska praksa pokazala da tumačenje socijalne države kao specifične kategorije dovodi do proizvoljnog presijecanja njezinih veza sa strukturama koje bi je trebale ostvarivati, što uključuje porezni sustav. Time se USRH ujedno omogućuje izbor između više naizgled odvojenih argumentacijskih pravaca u odlučivanju o pojedinim slučajevima, pri čemu nije sasvim jasno zbog čega se pojedine probleme ne može razmatrati i u svjetlu socijalne države.

$\mathrm{U}$ radu je interes usmjeren poglavito na porezni sustav te se ustavnosudski tretman istoga koristi u svrhu dva cilja. Prije svega, ističe se da uzdržanost u konkretiziranju socijalne države ujedno stvara neprihvatljiv prostor arbitrarne ustavnosudske pasivnosti prema zakonodavcu. Socijalna država nije samo specifičan koncept kojemu se može pridavati neki autonoman i isprazan značaj, već je odrednica hrvatskog ustavnog identiteta koja kao takva treba usmjeravati tumačenje s njome povezanih struktura. Nadalje, takvo poimanje uloge USRH ne znači i pristajanje na politički hiperaktivno ustavno sudovanje. Granice svojeg legitimnog djelovanja USRH ne bi trebao tražiti u granicama samog koncepta socijalne države, odnosno njegovoj političnosti, nego upravo u već primijećenim ograničenjima modaliteta kojima kao ustavno sudište raspolaže. Takvo djelovanje traži kvalitetniju i promišljeniju argumentaciju socijalne države, ali i posezanje za instrumentima nadzora koji nadilaze odrješito ukidanje zakona ili drugog propisa. Ono ujedno izbjegava značenjsko osiromašenje socijalne države u uvjetima u kojima je zakonodavna i izvršna vlast neopravdano mogu svesti na puki retorički ukras hrvatskog ustavnog zdanja.

4 Ustav Republike Hrvatske, Narodne novine br. 56/90, 135/97, 8/98 - pročišćeni tekst, 113/00, 124/00 - pročišćeni tekst, 28/01, 41/01 - pročišćeni tekst, 55/01 - ispravak, 76/10, 85/10 - pročišćeni tekst, 5/14 - Odluka Ustavnog suda br. SuP-O-1/2014 od 14. siječnja 2014.

5 Rodin S., op. cit. u bilj. 1, str. 116.

6 Ibid., str. 116. 
Supstantivni dio ovog rada započinje dijelom posvećenim razlikovanju između socijalne države, socijalnih prava te poreznog sustava. Koristeći odluku USRH o kriznom porezu kao temelj i kritičku pravnu teoriju kao analitičko sredstvo, ističe se zbog čega je izdvajanje socijalne države kao specifične kategorije potencijalno problematično. Sljedeći dio rada ta razmatranja usmjerava na porezni sustav koji, pokazuje se, jednim dijelom jest ili barem može biti određen ustavnom materijom koju, stoga, treba adekvatno tumačiti. Treći dio rada prikazuje nekoliko slučajeva u kojima je USRH to propustio učiniti upravo zanemarujući zahtjeve socijalne države. Dio rada koji prethodi zaključku utvrđuje kako alternativno, angažiranije tumačenje, ne mora nužno dovesti do iskakanja USRH iz granica svoje uloge. Ograničenost USRH nije u ograničenosti načela kojima raspolaže, već u granicama njegove uloge. Samoograničenje na toj osnovi može pružiti prostor za kvalitetnije tumačenje socijalne države, bez da se time istovremeno od USRH očekuje nastupanje u ulozi punokrvnog zakonodavca, što je svakako nada koja se ne može ispuniti.

\section{SOCIJALNA DRŽAVA KAO IZDVOJENI USTAVNOSUDSKI KRITERIJ}

U svojoj dobro poznatoj odluci o „kriznom porezu“ USRH je primijenio socioekonomski kategorijalni aparat URH kako bi utvrdio da je uvođenje predmetnog poreza u skladu s njime. Ulogu spornog poreza već se problematiziralo drugdje. ${ }^{7}$ Ovdje se nastoji zadržati na odluci kojom je njegova ustavnost potvrđena i istražiti mjesto socijalne države u njoj.

USRH je ispitivao krizni porez na podlozi svojih dobro poznatih gledišta o granicama nadzora porezne materije. Sažeto se može istaknuti kako ta polazišta ograničavaju prostor ustavnosudskog nadzora, prepuštajući središnju ulogu zakonodavcu. ${ }^{8}$ Ističući svoje jednako dobro poznato razumijevanje URH kao „cjeline“, koju takvom treba tumačiti, ${ }^{9}$ USRH preispituje ustavnost kriznog poreza s više osnova. Za ovaj su rad najvažnije dvije od njih, koncept socijalne države te načelo razmjernosti, kako u vidu članka 16. kao mjesta kodifikacije tog načela općenito, tako i u vidu posebnog razumijevanja „razmjernosti u snošenju javnih troškova“. ${ }^{10}$

Kada je ocjenjivao ustavnost kriznog poreza s aspekta socijalne države, USRH se u osnovi oslonio na njezin temeljni karakter, i to u dva pogleda. Prije svega, naglasio je njezinu izrazitu važnost za ustavni poredak, ističući kako se radi o sastavnom dijelu europskog i hrvatskog ustavnog identiteta. ${ }^{11}$ Nadalje, utvrdio je da socijalna

7 Cindori S. i Kuzelj V., Socijalni aspekt kriznoga poreza: fiskalni instrument ili devijacija poreznog sustava?, Ekonomska misao i praksa, sv. 27, br. 2, 2018., str. 479-502.

8 USRH, Odluka i Rješenje U-IP-3820/2009 i U-IP-3826/2009 i dr., od 17. studenoga 2009., para 10.

9 Ibid., para 11.

10 Loc cit.

$11 \quad$ Ibid., para 13.1. 
država predstavlja izvorište socijalne pravde kao najviše vrednote ustavnoga poretka te je $u$ tom smislu, zajedno $s$ tom vrednotom, i izvor niza socijalnih prava priznatih temeljnim aktom Republike Hrvatske. ${ }^{12} \mathrm{U}$ tom je smislu bilo za očekivati da će i razrada socijalne države biti niti vodiljom odluke.

Usprkos tomu i oslanjajući se na njemačku judikaturu, USRH je otpisao mogućnost podrobnije interpretacije zahtjeva socijalne države kao jednog apstraktnog zahtjeva čija je konkretizacija poglavito zadaća zakonodavca. Istaknuo je da bi se suprotnim postupanjem morao upustiti u svrsishodnost politički odabranih načina provedbe socio-ekonomskih dimenzija URH. ${ }^{13}$ Umjesto toga je zaključio kako je zahtjev socijalne države zadovoljen time što je dio potencijalnih obveznika, za koje je utvrdio posebnu ugroženost, oslobođen plaćanja spornog poreza. ${ }^{14}$ Načelo razmjernosti, kao opće načelo i u smislu primjenjivom specifično na poreze, analizirano je kao odvojeno pitanje. U tome je i jedna od najupadljivijih razlika između stava većine sudaca USRH te izdvojenog mišljenje sudaca Arlovića i Matije, koji su socijalnu državu i u njoj sadržanu socijalnu pravdu nastojali razmatrati združeno s ostalim osnovama ocjene ustavnosti kriznog poreza. ${ }^{15}$

U kontekstu ovoga rada od posebnog je interesa argumentacijski manevar odvajanja socijalne države od specifičnih standarda ustavne ocjene poreza. Upravo se po njemu može povući razlika između stava većine i izdvojenog mišljenja u odluci o kriznom porezu. Usprkos tome što je USRH započeo s dobro poznatim i poprilično nespornim gledištem da URH treba čitati „kao cjelinu“, socijalna je država razmatrana naizgled odvojeno od specifičnih ustavnih određenja vezanih za porezni sustav. Odbijanje USRH da socijalnu državu razmatra kao dio jedne takve cjeline, valja istaknuti, nije apolitičan čin.

Odluka USRH da ispituje socijalnu državu odvojeno od struktura koje su s njom povezane složenija je nego što se na prvi pogled čini. To je odvajanje koje zapravo predstavlja minimalističko čitanje socio-ekonomske dimenzije URH. Ovdje se ne radi o ,doktrini ekonomske neutralnosti Ustava prema gospodarskim politikama i slobodi izbora zakonodavca“" koju je Ustavni sud u predmetu Agrokor naknadno istaknuo kao odrednicu hrvatskog Ustava. ${ }^{16}$ Upravo suprotno, minimalističko čitanje socijalne države kao stavke koju se može razmatrati kao jedno specifično i izolirano pitanje rezultat je tumačenja ustavne cjeline kao izraza neoliberalizma. U takvom viđenju socijalna prava, socijalna pravda i socijalna država kao njihova osnova trebaju osigurati pravično zadovoljenje ,,početnog minimuma potreba““ ${ }^{17}$ Ustavna kodifikacija socio-ekonomskih kategorija zaštitna je mreža te, „kao što

12 Ibid., para 13.1.-13.2.

13 Ibid., para 13.4.

14 Loc. cit.

15 Izdvojeno mišljenje uz Odluku i Rješenje broj: U-IP-3820/2009 i U-IP-3826/2009 i dr. od 17. studenoga 2009. godine, t. I.

16 O tome vidi i Kuzelj V.; Cindori S. i Horvat Vuković A., Apoteoza socijalne države: imperativni zahtjev ostvarenja socijalne pravde u Republici Hrvatskoj, Pravni vjesnik, sv. 37, br. 3-4, 2021. prihvaćen za objavu.

17 USRH, Odluka i Rješenje U-IP-3820/2009 i U-IP-3826/2009 i dr., od 17. studenoga 2009., para 13.1 . 
bi za sigurnosnu mrežu bilo pogubno da se upliće u izvedbe akrobata na trapezu“, tako i ustavnopravna sigurnosna mreža zapravo ne bi smjela izazivati materijalne neravnopravnosti koje nekoga dovode u položaj u kojem mu je potrebno osigurati ono što se smatra „minimumom“ ${ }^{18}$ Upravo takvo rezoniranje prožima odluku o kriznom porezu. Restriktivno tumačenje socijalne države i socijalne pravde dovodi do toga da zakonodavac mora samo relativno razumno obratiti pozornost na potrebe skupina koje se smatra najugroženijima. U tome, kao što se ističe u izdvojenom mišljenju, ${ }^{19}$ uopće nije bitno što izabrana mjera niti njezin ishod ne ispunjavaju uvjete socijalne pravde.

Iznesenu interpretaciju potvrđuje način na koji je USRH razmatrao mogućnost da određeno porezno opterećenje, usprkos svojoj generalno utvrđenoj razmjernosti, pretjerano pogađa pojedince. Pozivajući se na svoj dobro poznati konstrukt „faktične međusobne neusporedivosti privatnih imovinskih sfera pojedinaca u konkretnim slučajevima“", svodi ustavnu relevantnost takvih situacija na pojedinačne sporove. ${ }^{20}$ U takvom viđenju socijalna prava postaju politički neutralizirana, jer zahtjeve distributivne pravde povezane s njima nije moguće pretočiti u sudske sporove obilježene zahtjevom utuživosti. ${ }^{21}$ Nadalje, ona su izjednačena s već spomenutim „minimumom“ kojega su sudovi sposobni zaštititi. ${ }^{22}$ Pozitivne obveze države time su marginalizirane, iako su uvodno naglašene kao jedna bitna zasada socijalne države. ${ }^{23}$ Naprotiv, USRH je dubiozno ocijenio da se nesocijalnu poreznu mjeru može opravdati upravo potrebom namicanja sredstava za financiranje drugih dimenzija socijalne države. ${ }^{24}$ Takav je ishod moguć upravo stoga što je socijalna država tumačenjem odijeljena od ostalih socio-ekonomskih struktura unutar URH. Konačno, prostor za perpetuiranje ovakvog tumačenja osnažila je odluka USRH u predmetu Agrokor, utoliko što je USRH u nju ugradio i koncepciju tzv. ekonomske (gospodarske) neutralnosti ustava. Ukratko, njome se nalaže da URH ne predodređuje „ekonomsku doktrinu ni sustav ili smjer ekonomske politike“, jer to treba odrediti zakonodavac. ${ }^{25}$ Ukoliko se tumači u suglasnosti sa zahtjevima socijalne države, ova teorija načelno znači samo da zakonodavac treba imati prostor izbora gospodarskih i socijalnih politika. Tako je, prema stručnom mišljenju Kostadinov ugrađenom u odluku USRH, istaknuto i u judikaturi Saveznog ustavnog suda SR Njemačke. Izbori

18 Atria F. i Salgado, C., Social Rights, u: Christodoulidis E.; Dukes R. i Goldoni M. (ur.), Research handbook on critical legal theory, Routledge, New York, 2019., str. 363.

19 Vidi, primjerice, Izdvojeno mišljenje uz Odluku i Rješenje broj: U-IP-3820/2009 i U-IP-3826/2009 i dr. od 17. studenoga 2009. godine, t. IV. 14.2.

20 USRH, Odluka i Rješenje U-IP-3820/2009 i U-IP-3826/2009 i dr., od 17. studenoga 2009., para

21 Atria F.; Salgado C., op. cit. u bilj. 16, str. 373.

22 Ibid., str. 374.

23 USRH, Odluka i Rješenje U-IP-3820/2009 i U-IP-3826/2009 i dr., od 17. studenoga 2009., para 13.1.

24 Bačić A., O konstitucionalizaciji socijalnih prava i njihovu slabljenju prema sadržaju, Rad Hrvatske akademije znanosti i umjetnosti. Razred za društvene znanosti, br. 516=50, 2013., str. 195-203.; Cindori S. i Kuzelj V., op. cit. u bilj. 5, str. 490-496.

25 Relevantne dijelove stručnog mišljenja B. Kostadinov vidi u: USRH, Rješenje br. U-I-1694/2017, U-I-1793/2017 i dr. od 2. svibnja 2018., para. 29.5. 
zakonodavca moraju biti u skladu s jamstvom temeljnih prava (koja u suvremenosti dobivaju i socijalnu funkciju). ${ }^{26}$ Usprkos tome, ekonomska neutralnost ustava sama je po sebi naklonjena minimalističkom čitanju jamstava temeljnih prava. ${ }^{27}$ Stoga je potreban oprez kako se njeno isticanje u budućoj ustavnosudskoj jurisprudenciji ne bi tumačilo ne samo kao znak nužnog uvažavanja uloge zakonodavca, već i kao prostor dodatnog povlačenja USRH iz sfere tumačenja socijalne države.

Ovakvo čitanje izdvajanja socijalne države moglo bi se opravdavati Rodinovim poimanjem razlike između razrade subjektivnih prava te standarda socijalne države. U oba ova slučaja, može se tvrditi, zakonodavac treba svojim djelovanjem razraditi što spomenute kategorije konkretno znače. USRH je povjerena zadaća da kontrolira „granice“ te ovlasti. ${ }^{28}$ Takvo se objašnjenje teško može smatrati uvjerljivim. Utoliko što razlikovanje između ,stvaranja“konkretnog sadržaja subjektivnih pravai socijalne države uopće te kontrole „granica“ tog pothvata više zamagljuje nego što otkriva. Metaforom granice nastoji se stvoriti misaonu udaljenost od stvaranja sadržaja, kao da čuvanje granice samo po sebi ne doprinosi obliku sadržaja zahvaćenog njome i stoga predstavlja suštinski sadržajnu aktivnost. Wolin je uvjerljivo istaknuo kako je upravo to funkcija ustava kao instrumenata ,pripitomljavanja“ demokracije, povući granice koje će odijeliti „ustavno“ od „,neustavnog“, „moguće“ od „,nemogućeg“ te „poželjno od nepoželjnog“, odnosno pružiti oblik određenom sadržaju koji u granicama ostaje. ${ }^{29}$ Tvrditi da u tom pothvatu USRH ima ulogu graničara koji će spriječiti prelazak neke ex nihilo stvorene granice, odcijepljene od sadržaja koji tobože nastaje autonomno od ustavnih bedema (koje USRH navodno ne stvara), znači zamagliti moć kojom ustavno sudstvo raspolaže i omogućiti mu odricanje od mogućnosti bogatog i kreativnog tumačenja temeljnog akta u slučajevima u kojima bi za to bilo mjesta.

Obrana koja počiva na razlici između „ustavnog stvaranja“ i „ustavnog razgraničenja“ zapravo svoju osnovu ima u institucionalnim razlikama između ustavnih sudišta te zakonodavaca. Od ustavnog se suda ne očekuje kreativno djelovanje istovjetno zakonodavnom, stoga što nema izborni legitimitet niti institucionalni prostor usvajati i provoditi javne politike kao što to, naravno, mogu zakonodavna i izvršna vlast. Ipak, valja se čuvati izjednačavanja institucionalne različitosti i hijerarhijskog odnosa. URH predviđa diobu vlasti, ali ne i podređenost jedne vlasti drugoj. ${ }^{30}$ One su različite, ali moraju moći ravnopravno vršiti svoje

26 USRH, Rješenje br. U-I-1694/2017, U-I-1793/2017 i dr. od 2. svibnja 2018., para. 29.5.

27 Pinicione G., Constitutional neutrality among economic policies, Public Choice, sv. 152, br. 3-4, 2012., str. 456.

28 Rodin S., op. cit. u bilj. 1, str. 116.

29 Wolin S., Fugitive Democracy, u: Benhabib S. (ur.), Democracy and Difference. Contesting the Boundaries of the Political, Princeton University Press, Princeton, 1996., str. 34.

30 Ustav, naravno, priznaje instrumente ,provjere i ravnoteže“, ali njihovo postojanje samo po sebi ne bi moglo poslužiti razmatranju ustrojstva vlasti po svojevrsnom piramidalnom načelu, u kojem bi jedno tijelo moralo imati primat. Naprotiv, takva ideja u hrvatskom je kontekstu srodna načelu jedinstva vlasti, koje je u teoriji skupštinske vladavine imalo istaknuto mjesto, služeći upravo egzaltaciji predstavničkog organa naspram svih drugih, Smerdel B., Nekoliko poredbenih počela za raspravu o hrvatskom parlamentu, Politička misao, sv. 30, br. 4, 1993., str. 45. Imajući u vidu usvajanje diobe vlasti kao njemu dijametralno suprotnog principa, ne može biti govora o apriornoj hijerarhijskoj nadmoći ijedne vlasti. 
ovlasti. Shodno tome, i u skladu s najnovijim dosezima ustavne teorije, ${ }^{31}$ USRH treba razumjeti kao specifičnog aktera koji zbog toga nema izmijenjeni kvantum ovlasti u odnosu na, primjerice, zakonodavca. Njegove su ovlasti jednostavno drugačije, ali to samo po sebi nije razlog da ih se vrši u smanjenom opsegu.

Moglo bi se tvrditi da inzistiranje na ovakvom tumačenju može imati nepoželjan učinak utoliko što bi USRH moglo izvesti iz granica njegove uloge, preobražavajući ga ipak u svojevrsnog „,kvazi-zakonodavca“. Na to se mogu pružiti dva odgovora. Prije svega, uobičajeni narativ o opasnosti od hiperaktivnog ustavnog sudstva zanemaruje da se ustavom ne uređuje pojedine institucije u vakuumu, već se uređuju i njihovi međusobni odnosi. Ukoliko USRH ne postavlja razložne granice drugim institucijama, postoji opasnost da će druge vlasti, posebno ona zakonodavna, same izaći iz granica vlastitih uloga u pogledu zaštite socijalne države. Naličje umnažanja pitanja o kojima USRH nema što za reći stoga je umnažanje prostora snaženja drugih grana vlasti, što samo po sebi nije ustavno poželjno. Nadalje, bojazan od otklizavanja USRH u pretjeranu političnost pretjerano je radikalna. Kao što će se u nastavku pokazati, to što bi USRH mogao priznati puninu svoje kreativne uloge ne znači da bi nužno istisnuo predstavničko tijelo i izvršnu vlast, poništavajući prostor njihovog djelovanja.

U nastavku će se razraditi odgovor na ovaj prigovor, usmjeravajući se na ustavne dimenzije poreznog sustava. Sukladno supra iznesenom, USRH je u odluci o kriznom porezu razdvojio standarde procjene tog sustava od socijalne države, čime je dao velik prostor ovlastima zakonodavne i izvršne vlasti. U sljedećem dijelu rada pokazat će se da je takvo poimanje nesukladno tome što osnove poreznog sustava počivaju u URH, kao i njihovoj vezi sa socijalnom državom. Zatim će se na nekoliko primjera pokazati pogubne propuste ustavnosudskog uzdržavanja od inzistiranja na toj vezi. Konačno, pokazat će se da USRH takvim inzistiranjem ne mora nužno iskoračiti iz svoje Ustavom zadane uloge.

\section{IMPLIKACIJE USTAVNIH NAČELA OPOREZIVANJA U KONTEKSTU TEMELJNE SOCIJALNE OPREDIJELJENOSTI HRVATSKOGA USTAVA}

Iznalaženje primjerenog i prihvatljivog normativnog oblika financiranja državnih zadaća predstavlja primarno pitanje poreznog prava. ${ }^{32} \mathrm{U}$ tom je smislu poreznu politiku moguće definirati „,kao ukupnost poreznih mjera neke države, usmjerenih ostvarenju određenih političkih ciljeva“",33 pri čemu poreze, kao

31 Vidi, primjerice, Kavanagh A., Recasting the Political Constitution: From Rivals to Relationships, King's Law Journal, sv. 30, br. 1, 2019., str. 43-73.

32 Mijatović N., Teorijsko razmatranje nekih odrednica poreznog sustava, Hrvatska pravna revija, br. 2, 2016., str. 19 .

${ }_{33}$ Mijatović N., Teorijsko razmatranje nekih odrednica poreznog sustava (II. dio), Hrvatska pravna revija, br. 3,2017 ., str. 20 . 
najizdašniji oblik sredstava namijenjenih njihovoj realizaciji, država namiruje temeljem svojeg fiskalnog suvereniteta, tj. ovlasti samostalnog uređenja sustava javnih prihoda i rashoda. ${ }^{34}$ Fiskalni suverenitet, shvaćen kao apsolutno subjektivno proračunsko pravo legislative, rezultat je višestoljetnog razvoja parlamentarizma i predstavlja jednu od temeljnih odlika predstavničke demokracije. ${ }^{35}$ Tako je u ustavnim dokumentima suvremenih europskih demokracija uočljiva visoka razina konvergencije u reguliranju porezne materije kroz zahtjev općeg pristanka na oporezivanje te je eksplicite izražena potreba korištenja zakonske forme za uređenje i modificiranje poreznih instrumenata. ${ }^{36}$ Nastavno, iako zakonski oblik utvrđenja porezne obveze predstavlja jedan od temeljnih postulata predstavničke demokracije (izražen maksimom američke revolucije: „No taxation without representation “37), pogrešan je zaključak kako su ,[s]vi porezi u modernoj (...) državi oblikovani i utvrđeni zakonom“ te da „,[s]ukladno tomu, pravednost pravnog [a samim time i poreznog, op. a.] sustava određuje zakonodavac"..$^{38}$

Naime, u suvremenim ustavnim državama odluka o temeljnim ciljevima društva koje država treba ostvariti ne pripada u isključivu nadležnost političkih grana vlasti, tj. ne predstavlja tek rezultat političkog pregovaranja. Demokratski ustavi definiraju temeljne vrijednosti (društvene ciljeve), čijem ostvarenju i operacionalizaciji politička tijela vlasti trebaju stremiti, dok se odabir modela njihova ostvarenja prepušta pregovaranju političkih aktera i odlučuje kroz rezultat izborne utakmice. ${ }^{39}$ Takvo shvaćanje proizlazi iz činjenice da su ,suvremeni ustavni dokumenti namijenjeni odvajanju fundamentalnih načela političke zajednice od redovitih političkih procesa“". ${ }^{40}$ Iako je rjeđa pojava da se ustavnim tekstovima pokuša regulirati sadržaj i odnos vrijednosti (načela) u sferi oporezivanja te posljedično utjecati na sadržaj legislativnih odluka u pogledu dizajna poreznog sustava, ustavi zemalja latinske

34 Mijatović N., Teorijsko razmatranje osnovnih odrednica poreznog sustava (III. dio), Hrvatska pravna revija, br. 4, 2018., str. 28.; vidi i Goreta M.; Peran B. i Vukošić K., Originarni $i$ derivativni prihodi države, Zbornik radova Veleučilišta u Šibeniku, br. 1-2, 2016., str. 187-188.

35 O isprepletenosti razvoja parlamentarizma i fiskalnog suvereniteta u Engleskoj vidi Marelja M. i Kuzelj V., Evolucija fiskalnoga suvereniteta u Engleskoj: od sredstva ograničenja vladara do prerogativa zakonodavne vlasti, Zbornik Pravnog fakulteta Sveučilišta u Rijeci, sv. 41, br. 2, 2020., str. 509-529.

36 Boria P., Taxation in European Union, Springer, Cham, 2017., str. 12.

37 Američka revolucija vuče korijene iz činjenice da su Povelje (engl. Charters) engleskog Parlamenta doseljenicima (kolonizatorima) jamčile „sva prava, privilegije i imunitete“ engleskih građana, iz čega bi (dosljedno provedeno) proizlazila i zabrana nametanja poreza bez njihova ,pristanka“. S obzirom da engleski građani u kolonijama nisu bili zastupljeni u engleskom Parlamentu, nije postojala mogućnost davanja ,pristanka“ na poreze (i druge zakone) putem izabranih parlamentarnih predstavnika te su njihova „prava kao Engleza bila iluzorna“, Adams C., For Good and Evil : The Impact of Taxes on the Course of Civilization, Madison Books, Lanham, 2001., str. 301-302.

38 Perić R. i Szilovics C., Pravednost i jednakost u sustavima poreza na dohodak, u: Župan M. i Vinković M. (ur.), Suvremeni pravni izazovi: EU - Mađarska - Hrvatska, Pravni fakultet Sveučilišta u Pečuhu, Pravni fakultet Sveučilišta J. J. Strossmayera u Osijeku, Pečuh - Osijek, 2012., str. 243.

39 U poustavljenom poretku, ,zakonodavstvo je uvjetovano ustavom u smislu što se ono više ne shvaća kao 's obzirom na cilj slobodna' djelatnost, nego pak kao 'diskrecijska' djelatnost, usmjerena na konkretiziranje ustava“, Guastini R., Sintaksa prava, Naklada Breza, Zagreb, 2016., str. 186.

40 Miloš M., Reading the Constitution as an Integrated Whole: an Exploration of an Interpretative Instrument, u: Sander G. G.; Pošćić A. i Martinović A. (ur.), Exploring the Social Dimension of Europe : Essays in Honour of Nada Bodiroga-Vukobrat, Verlag Dr. Kovač, Hamburg, 2021., str. 569. 
tradicije (npr. Italija, Portugal, Španjolska) uvode kriterij oporezivanja sukladno ekonomskoj snazi poreznog obveznika, uspostavljajući time redistributivno načelo nasuprot (isključivo) fiskalnom cilju izdašnosti poreznih prihoda. Ponegdje se (npr. Italija, Španjolska) odlazi i korak dalje te se postulira načelo progresivnosti poreznog sustava. ${ }^{41}$

Potrebno je istaknuti kako nedostatak specifičnih ustavnih odredbi o ciljevima i obliku poreznog sustava ne treba shvaćati kao prepuštanje čitave porezne materije diskreciji zakonodavne vlasti. Umjesto toga, valja se zalagati za holističko shvaćanje ustava koje ga izdvaja iz sfere redovitog zakonodavstva i dnevnih politika te se, uz potrebu njegova tumačenja kao pozitivno-pravnog dokumenta, primarnim ističe shvaćanje cjeline prožete određenim vrednotama i aspiracijama, koje predstavljaju viziju ustava kao simboličkog registra čije vrijednosti nadilaze pisani dokument. ${ }^{42}$ Cjelina ustavnih vrijednosti kao temeljnog određenja društvene zajednice prožima i sferu oporezivanja te se ovlast zakonskog uređenja poreznog sustava ograničava tim fundamentalnim državnim usmjerenjem, koje nije ostavljeno na raspolaganje trenutnoj političkoj volji. Tako iz ustavnog koncepta socijalne države njemački Savezni ustavni sud izvodi egalitarno shvaćanje pojma jednakosti te inzistira na potrebi zakonodavčeve predanosti ostvarenju određenih socijalnih vrijednosti u cilju postizanja veće razine ekonomske jednakosti, a njegov ,,agresivan nadzor ustavnosti poreznog zakonodavstva odražava važnost poreza kao najefektivnijeg mehanizma socijalnih promjena" ${ }^{43}$ Pritom poimanje načela oporezivanja sukladno ekonomskoj snazi u njemačkoj ustavnosudskoj praksi, kao temeljne norme poreznog sustava, valja shvatiti kao odbacivanje utilitarnih ekonomskih principa. ${ }^{44}$

Potreba ograničenja spektra zakonodavne diskrecije pri uređenju fiskalnog sustava proizlazi iz činjenice da je oporezivanje „besprimjerni socijalni fenomen“ u kojem se susreću dva (naizgled) suprotstavljena interesa: nositelja fiskalne vlasti i građana (poreznih obveznika) te se stoga postizanje pravednosti u oporezivanju ističe kao „,nezaobilazni (...) normativni zahtjev koji se postavlja pred nositelje porezne politike " ${ }^{45} \mathrm{U}$ tom smislu URH ograničava fiskalni suverenitet parlamenta poustavljenjem socijalno-političkih načela oporezivanja (čl. 51.), čime potvrđuje da „legitimitet porezne politike ne proizlazi tek iz ustavnog ovlaštenja uređenja poreznog sustava, već iz njegove pravednosti i socijalne osjetljivosti “" ${ }^{46}$ Time se ograničava općenitija ustavna ovlast hrvatskog zakonodavca da proračunom utvrđuje državne prihode i rashode (čl. 91., st. 1.-2.). ${ }^{47}$ Ustavnosudsko se tumačenje pritom

41 Boria P., op. cit. u bilj. 34, str. 14.

42 Miloš M., op. cit. u bilj. 38, str. 571.

43 Barker W. B., The Three Faces of Equality: Constitutional Requirements in Taxation, Case Western Reserve Law Review, sv. 57, br. 1, 2006., str. 49.

44 Ibid., str. 50.

45 Gadžo S., Prilog istraživanju sadržaja načela pravednosti kao kriterija evaluacije normi međunarodnog poreznog prava, Pravni vjesnik, sv. 31, br. 2, 2015., str. 134.

46 Cindori S. i Kuzelj V., op. cit. u bilj. 5, str. 482.

47 Kuzelj V., Porezna pravednost: Conditio sine qua non socijalne države, Pravnik, sv. 52, br. 103, 2018., str. 101 . 
mora temeljiti na cjelovitom pristupu te se pojedine odredbe ne mogu tumačiti „Zasebno i mehanički“, bez uzimanja u obzir pluralizma ustavnih vrijednosti i cjeline ustavnoga teksta, pri čemu se posebno ističe značaj najviših ustavnih vrednota (čl. 3.) ${ }^{48} \mathrm{~s}$ obzirom da se upravo kroz ostvarivanje vrednota legitimira ustavni poredak, a ,[u]stav bez legitimnosti nije nikakav ustav“. ${ }^{49}$

Usprkos općem slaganju o potrebi ostvarenja veće razine pravednosti u oporezivanju, ,,mnogo je nesporazuma oko toga što pravednost zapravo znači“ “. .0 $^{\circ}$ Pritom je kod procjene razine pravednosti u oporezivanju potrebno sagledati porezni sustav u cjelini, s obzirom da se samo koordinacijom poreznih instrumenata mogu otkloniti ili ublažiti negativni efekti pojedinog poreznog oblika. ${ }^{51}$ Tako valja razlikovati formalnu dimenziju porezne pravednosti koja počiva na analizi određenih aspekata odnosa između nositelja porezne vlasti i građana (poreznih obveznika) te materijalnu dimenziju temeljenu na usporedbi (ne)jednakog položaja poreznih obveznika, pri čemu potonja odgovara na pitanje o poželjnoj raspodjeli poreznog tereta pri kreiranju poreznih politika. Pritom se općeprihvaćenim mjerilom pravednosti ističe načelo plaćanja poreza sukladno ekonomskoj snazi poreznog obveznika, temeljeno na solidarnosti pripadnika društvene zajednice. Načelo ekonomske snage (gospodarskih mogućnosti) „tako je odraz općeg načela jednakosti (...) koje je, kao produkt povijesnih borbi pod barjakom ideje ljudskih prava, opće mjesto ustavnog poretka većine suvremenih država" ${ }^{52} \mathrm{U}$ tom smislu, iz odredbe URH kako se porezni sustav RH (a ne pojedini porezni oblik) ima temeljiti na načelima jednakosti i pravednosti (čl. 51., st. 2.) razvidno je ustavotvorčevo pomirenje dvaju (naizgled suprotstavljenih) poreznih načela: pravednosti i efikasnosti. Time je omogućeno ostvarenje fiskalnoga cilja (punjenja proračuna) putem izdašnih, ali regresivnih (neizravnih) poreza, dok je ispravljanje njihovih negativnih posljedica omogućeno korištenjem drugih poreznih instrumenata. Stoga je od najveće važnosti poznavanje sadržaja ustavnih načela oporezivanja kao smjernica zakonodavcu pri kreiranju poreznih politika te u svrhu zaštite tako shvaćenog ustavnog minimuma prava poreznih obveznika.

Iz čl. 51. URH, kao jedine ustavne odredbe koja verbatim navodi načela uređenja poreznog sustava, proizlazi zahtjev univerzalnosti porezne obveze (,,svatko je dužan sudjelovati“), poštovanja načela ekonomske snage (,,u skladu sa svojim ekonomskim mogućnostima"), jednakosti i pravednosti u oporezivanju. Iz načela porezne pravednosti (čl. 51., st. 2.) proizlazi deklaratorna predanost ustavotvorca socijalnim ciljevima poreznog sustava, dok je njegov sadržaj određen ostalim odredbama

48 Šarin D., Ustavni sud Republike Hrvatske kao institucionalni zaštitnik ljudskih prava i temeljnih sloboda, Zbornik radova Pravnog fakulteta u Splitu, sv. 52, br. 3, 2015., str. 762.

49 Bačić A., Mjesto i uloga ustavnih vrednota u demokratskom konstitucionalizmu, u: Bačić A. (ur.), Dvadeseta obljetnica Ustava Republike Hrvatske, Hrvatska akademija znanosti i umjetnosti, Zagreb, 2011., str. 161.; Bačić A., Ustav Republike Hrvatske i najviše vrednote ustavnog poretka, Zbornik radova Pravnog fakulteta u Splitu, sv. 49, br. 1, 2012., str. 17.

50 Kesner-Škreb M., Pravednost poreza, Financijska teorija i praksa, sv. 26, br. 3, 2002., str. 713.

51 Šimović J., Socijalni učinci poreza na dodanu vrijednost, Revija za socijalnu politiku, sv. 5, br. 2-3, 1998., str. 100.

52 Gadžo S., op. cit. u bilj. 43, str. 135. 
istoga članka, kao zahtjev za ostvarenjem vertikalne i horizontalne pravednosti u oporezivanju. Navedene lex specialis odredbe o dizajnu poreznog sustava (čl. 51.) valja tumačiti u kontekstu cjeline ustavnoga teksta (holistička interpretacija Ustava), uzimajući u obzir temeljno opredjeljenje RH konceptu socijalne države (čl. 1., st. 1.) i načelu socijalne pravde (čl. 3.). ${ }^{53}$

Iz iznesenoga je moguće zaključiti kako hrvatski ustavotvorac odbacuje tzv. klasično poimanje jednakosti kao (isključivo) formalne jednakosti pred zakonom, koja onemogućava afirmativno državno djelovanje u cilju ispravljanja položaja socijalno ugroženih skupina. Također je neprihvatljiva isključivost shvaćanja tzv. popularne jednakosti kao odraza trenutačnog političkog izbora, temeljenog na ideji kako zakonodavcu (kao predstavniku aktualne političke volje građana) pripada diskrecijsko pravo određivanja sadržaja načela jednakosti. Naprotiv, u kontekstu suvremene RH jedino je moguće prihvaćanje koncepta tzv. socijalne jednakosti kao načela proizišlog iz ustavne vizije društva koje stremi jednakosti kroz pravednu redistribuciju resursa. To je načelo pritom osnaženo omogućavanjem (ustavno) sudske intervencije u porezno zakonodavstvo s ciljem nadzora državne aktivnosti u smjeru ostvarenja (socijalno) pravednijeg poretka. ${ }^{54}$

\section{POSLJEDICE NEADEKVATNOG ANGAŽIRANJA SOCIJALNE DRŽAVE U NADZORU POREZNOG SUSTAVA}

Prethodna dva dijela rada ukazala su da je USRH u svojoj praksi pokazao sklonost tumačenju URH u skladu s neoliberalnim polazištima. Zatim je istaknuto da takvo razumijevanje ustavne cjeline nije jedino moguće. Hrvatski temeljni akt zapravo nudi vokabular kojim se može i mora socio-ekonomske ustavne strukture tumačiti upravo kako bi se izbjeglo pojednostavljenje i osiromašenje uloge socijalne države i u uređenju i provedbi poreznog sustava. U ovom će se dijelu na temelju dva primjera prikazati koje su posljedice propusta USRH da takvo tumačenje i usvoji.

Osim u već spomenutoj odluci o kriznom porezu, USRH je više puta odlučivao o suglasnosti poreznih zakona s URH. Tako je, primjerice, ukinuo odredbe Zakona o financiranju jedinica lokalne i područne (regionalne) samouprave ${ }^{55}$ zbog nesuglasnosti s jamstvom prava vlasništva (čl. 48.) i ustavnim načelima oporezivanja (čl. 51.), ističući kako instrumenti porezne politike ne mogu biti korišteni za penalizaciju ili prisiljavanje poreznih obveznika (vlasnika) da se

53 Arbutina H., Ustavna i nadnacionalna ograničenja ovlaštenja na oporezivanje, Zbornik Pravnog fakulteta u Zagrebu, sv. 62, br. 5-6, 2012., str. 1286-1288.

54 Detaljnije o pojmovima tzv. klasične, popularne i socijalne jednakosti vidi Barker W. B., op. cit. u bilj. 41, str. 48.

55 Zakon o financiranju jedinica lokalne i područne (regionalne) samouprave, Narodne novine br. 117/93, 69/97, 33/00, 73/00, 127/00, 59/01, 107/01, 117/01, 150/02, 147/03. 
na određeni način koriste svojim vlasništvom..$^{56}$ Moglo bi se zaključiti kako iz pregleda ustavnosudske prakse proizlazi ,ustaljeno stajalište da u odnosu na opće mjere gospodarske i socijalne politike zakonodavac ima široko područje slobodne procjene, pa je Ustavni sud dužan poštovati izbor zakonodavne politike". ${ }^{57}$ Time se otvara prostor pretjeranoj ustavnosudskoj pasivnosti na kojega je već upozoreno u kontekstu tumačenja socijalne države (vidi supra).

Navedeno je ponajprije vidljivo iz dugotrajne aberacije hrvatskog poreznog sustava koja je u eklatantnoj suprotnosti s ustavnim načelima oporezivanja (čl. 51.) te načelom jednakosti pred zakonom (čl. 14.). Riječ je o mogućnosti izbora i/ili obvezi prijelaza poreznih obveznika (fizičkih osoba) koji stječu dohodak od samostalne djelatnosti iz sustava oporezivanja dohotka u sustav oporezivanja dobiti. Upravo je pasivnost USRH razlog opstojnosti takvog legislativnog rješenja, s obzirom da u okviru učestalih izmjena poreznog zakonodavstva (gotovo na godišnjoj razini) zakonodavac odbija iz poreznog sustava otkloniti ovo, po svoj prilici jedinstveno hrvatsko rješenje, jer nije poznato ,da je takvo ili neko tome slično rješenje našlo primjenu u sustavu oporezivanja drugih zemalja“ ${ }^{58}$ Tako i aktualni Zakon o porezu na dohodak ${ }^{59}$ te Zakon o porezu na dobit ${ }^{60}$ predviđaju mogućnost, odnosno obvezu dijela poreznih obveznika (fizičkih osoba koje obavljaju samostalnu djelatnost) na plaćanje poreza na dobit, umjesto poreza na dohodak. Pritom se jedinom problematičnom točkom ne ističe tek najočitija nepravednost, ogledana u činjenici da se porez na dohodak plaća prema stopama od 20, odnosno $30 \%,{ }^{61}$ a porez na dobit po stopi od 10, odnosno $18 \% .{ }^{62} \mathrm{~S}$ gledišta načela jednakosti, postavlja se pitanje iz kojih se razloga samo neki porezni obveznici mogu koristiti tom pogodnošću te zašto odluka o prijelazu iz sustava poreza na dohodak u sustav poreza na dobit nije isključivo dobrovoljna, $\mathrm{tj}$. zbog čega je pod određenim okolnostima porezni obveznik prisiljen plaćati porez na dobit. ${ }^{63}$

Opisano zakonsko rješenje bilo je predmetom ocjene ustavnosti te predstavlja ogledni primjer pretjeranog ustavnosudskog samoograničenja. Naime, sukladno navodima predlagatelja, mogućnost i/ili obveza poreznih obveznika da plaćaju porez na dobit po znatno nižoj stopi od poreza na dohodak (uvećanog za prirez porezu na dohodak), predstavlja neopravdani porezni privilegij i povredu načela ravnomjerne

56 Vidi USRH, Odluka br. U-I-1559/2001, U-I-2355/2002 od 21. veljače 2007.; vidi i Cindori S. i Kuzelj V., Inadmissibility of Penal and Confiscatory Taxes, u: 5th International Multidisciplinary Scientific Conference Social Sciences \& Arts SGEM 2018, Conference proceedings, sv. 5, br. 1.2, Albena, 2018., str. 588 .

57 USRH, Rješenje br. U-I-3610/2010 i dr. od 15. prosinca 2010., para. 24.

58 Jelčić Bo., Je li nam nužna mala porezna reforma?, Informator, sv. 59, br. 5970, 2011., str. 3.

59 Zakon o porezu na dohodak, Narodne novine br. 115/16, 106/18, 121/19, 32/20, 138/20, čl. 36.

60 Zakon o porezu na dobit, Narodne novine br. 177/04, 90/05, 57/06, 146/08, 80/10, 22/12, 148/13, 143/14, 50/16, 115/16, 106/18, 121/19, 32/20, 138/20, čl. 2, st. 3.

61 Zakon o porezu na dohodak, Narodne novine br. 115/16, 106/18, 121/19, 32/20, 138/20, čl. 19.

62 Zakon o porezu na dobit, Narodne novine br. 177/04, 90/05, 57/06, 146/08, 80/10, 22/12, 148/13, 143/14, 50/16, 115/16, 106/18, 121/19, 32/20, 138/20, čl. 28.

63 Jelčić Ba., Porezni sustav i porezna politika po mjeri Hrvatske, Financije i porezi, br. 6, 2007., str. 51 . 
raspodjele poreznog tereta sadržanog u čl. 51. URH. Također, privilegiranje poreznih obveznika koji stječu dohodak s osnove samostalne djelatnosti dovodi do diskriminacije poreznih obveznika koji dohodak ostvaruju iz drugih izvora te se opisanim odredbama krši i opće ustavno načelo jednakosti pred zakonom i zabrane diskriminacije (čl. 14.). ${ }^{64}$

Razočarava što se USRH zadržao tek na načelnim stajalištima o ovlastima zakonodavne vlasti u pogledu fiskalnoga sustava te mogućnostima ustavnosudske (pr)ocjene njihove ustavnosti. Naime, pozivajući se na ustavnu odredbu o ovlasti hrvatskog zakonodavca na samostalno uređenje gospodarskih, pravnih i političkih odnosa u skladu s Ustavom i zakonom (čl. 2., st. 4., alineja 1.), izveo je zaključak o načelnoj zakonodavnoj slobodi pri uređivanju poreznih pitanja (uz obvezu poštovanja načela jednakosti i pravednosti ${ }^{65}$ te kako propisivanje, inter alia, kruga poreznih obveznika i visine poreznih stopa ne može biti ustavnopravno pitanje. ${ }^{66}$ U pogledu pitanja diskriminatornog tretmana poreznih obveznika (fizičkih osoba) koje dohodak stječu iz različitih izvora, USRH je izveo začudno objašnjenje prema kojem je kao relevantnu činjenicu pri ocjeni poštovanja načela jednakosti pred zakonom (čl. 14., st. 2.) razmatrao odnosi li se ona na sve porezne obveznike (fizičke osobe) koje dohodak ostvaruju temeljem samostalne djelatnosti. S obzirom da je odgovor potvrdan, tj. da nema diskriminacije među njima, u nastavku zaključuje kako promjena u oporezivanju te skupine poreznih obveznika nije protivna ustavnim načelima jednakosti (čl. 14., st. 2.) ili poreznog sustava (čl. 51.) ${ }^{67}$ Slično stajalište USRH iznosi u Rješenju o ocjeni ustavnosti Zakona o smanjenju mirovina određenih, odnosno ostvarenih prema posebnim propisima o mirovinskom osiguranju, ${ }^{68}$ ističući kako je ,zakonodavac slobodan procijeniti opravdava li različitost i u kojoj mjeri, u inače sličnim situacijama, različito uređenje prava i obveza, pri čemu opseg njegovih ovlasti ovisi o predmetu zakonskog uređenja i s njim povezanim činjenicama i okolnostima“.

Navedena stajališta USRH rezultat su pretjerane pasivnosti prema zakonodavcu. Naime, u Rješenju o prijelazu iz sustava oporezivanja dohotka u sustav oporezivanja dobiti USRH iznosi nekoliko, s doktrinarnog gledišta, dubioznih zaključaka koji ne mogu podnijeti teret ispitivanja sa stajališta teleološke interpretacije URH. Već pri određivanju načelne zakonodavne slobode pri uređivanju poreznog sustava, USRH zanemaruje ključni dio čl. 2., st. 4. alineje 1. koji utvrđuje ovlast hrvatskog zakonodavca na uređenje gospodarskog, pravnog i političkog sustava, ali u skladu s Ustavom i zakonom. URH, a što bi bio slučaj i bez eksplicitne odredbe o tome, predstavlja krajnju granicu legislativne diskrecije pri uređenju poreznog sustava te dužnost USRH na zaštitu načela i vrednota koje prožimaju cjelinu ustavnoga teksta. Stoga se pretjerano samoograničenje, gotovo odricanje, USRH u pogledu ovlasti

64 USRH, Rješenje br. U-I-2012/2007 od 17. lipnja 2009., para. 3.

${ }_{65}$ Ibid., para. 6.

${ }_{66}$ Ibid., para. 8.

67 Ibid., para. 9.-10.

${ }_{68}$ Zakon o smanjenju mirovina određenih, odnosno ostvarenih prema posebnim propisima o mirovinskom osiguranju, Narodne novine br. 71/10. 
pri kontroli poreznog zakonodavstva ne može iščitati drugačije nego kao pasivnost prema zakonodavnoj vlasti. Nadalje, odraz je pretjeranog formalizma i pogrešne interpretacije ustavnih načela jednakosti pred zakonom (čl. 14., st. 2.) i porezne jednakosti (čl. 51., st. 2.), shvaćenog kao odraz načela horizontalne pravednosti, ograničavanje ustavnosudske ocjene isključivo na činjenicu da se osporene odredbe primjenjuju na sve porezne obveznike (fizičke osobe) koje dohodak ostvaruju temeljem samostalne djelatnosti, tj. da ne postoji diskriminacija među njima. Samostalna djelatnost samo je jedan od načina stjecanja dohotka ${ }^{69}$ fizičkih osoba te ne predstavlja odraz njihove ekonomske snage. Stoga se povoljniji tretman fizičkih osoba koje dohodak stječu temeljem samostalnih djelatnosti (kroz plaćanje poreza na dobit umjesto poreza na dohodak) ne može opravdati činjenicom da među njima samima ne postoji diskriminacija. Naime, s obzirom na niže porezno opterećenje porezom na dobit ti se porezni obveznici stavljaju u povoljniji položaj u odnosu na one koji dohodak ostvaruju iz drugih izvora, ne vodeći računa o odnosu njihove ekonomske snage, već isključivo o izvoru njihovih dohodaka, što je u eklatantnoj suprotnosti sa zahtjevima da osobe jednakih gospodarskih mogućnosti snose jednak porezni teret (horizontalna pravednost, čl. 51., st. 2. URH), dok osobe veće ekonomske snage trebaju snositi veći dio poreznog tereta (vertikalna pravednost, čl. 51., st. 1. URH). Iz navedenoga ne preostaje drugo nego zaključiti kako zakonska mogućnost i/ili obveza prelaska određene kategorije poreznih obveznika (fizičkih osoba) iz sustava poreza na dohodak u sustav poreza na dobit ne predstavlja izraz legislativne diskrecije, već ,upravo krajnji izraz proizvoljnosti zakonodavca, bez legitimnog cilja kojim bi takvo postupanje bilo opravdano"70 te je stoga par excellence ustavnosudsko pitanje.

Ovakvo postupanje USRH naspram poreznog sustava izaziva dvije ustavnopravno problematične posljedice. Prvu je moguće nazvati legitimacijom solilokvijskog tumačenja ustavnih vrijednosti. Ukratko, zakonodavno tijelo pozvano je tumačiti URH u vršenju svojih ovlasti, ali ne može mu se dati neograničena ovlast u pridavanju značaja pojedinim ustavnim odrednicama. USRH je ključan instrument ,provjere i ravnoteže" u tom smislu. U konačnici, zbiljski se ustav ogleda kroz prihvaćanje ustava od strane građana te njegovu dosljednu provedbu kroz zakonodavstvo, odluke (ustavno)sudske vlasti i djelovanje političkih grana vlasti. ${ }^{71} \mathrm{U}$ tom smislu nema sumnje da suvremene demokratske i socijalne države prožima pluralizam interesa koji ne mogu biti uvijek ostvareni na optimalnoj razini. Naprotiv, upravo je balansiranje između suprotstavljenih težnji u okviru iste političke zajednice stavljeno u zadatak predstavničkih tijela koja moraju osigurati dostatna sredstva za

69 Zakon o porezu na dohodak, Narodne novine br. 115/16, 106/18, 121/19, 32/20, 138/20, čl. 5.

70 Kuzelj V., Komplementarnost ustavnopravnih $i$ društvenih odrednica porezne pravednosti $u$ Republici Hrvatskoj, u: Bevanda V. (ur.), EMAN 2020 - Economics \& Management: Hot to Cope with Disrupted Times, Conference Proceedings, Association of Economists and Managers of the Balkans, Beograd, 2020., str. 473.

71 Smerdel B., Zadaće pravne znanosti i pravničke struke na dvadesetu obljetnicu „Božićnog Ustava“ - ustavni izbor i procesi ostvarivanja najviših ustavnih vrednota i strateških ciljeva Republike Hrvatske, u: Bačić A. (ur.), Dvadeseta obljetnica Ustava Republike, Hrvatska akademija znanosti i umjetnosti, Zagreb, 2011., str. 44-45. 
financiranje državnih zadaća (među koje nedvojbeno pripada i ostvarenje socijalnih ciljeva), ali na način da prikupljanje takvih prihoda ne bude ocijenjeno nesocijalnim i nepravednim. U tom je svjetlu neophodno održati snagu ustavnih odredbi u pogledu oporezivanja kao minimalnih zahtjeva porezne pravednosti kojima zakonodavac mora udovoljiti prilikom propisivanja pojedinih poreznih oblika te dizajna poreznog sustava u cjelini, neovisno o tome što je „ocjena svrsishodnosti, racionalnosti te ostvarenja višeg stupnja porezne pravednosti od ustavnog minimuma prepuštena građanima koji mogu javni dojam o tim pitanjima pretočiti u glasove za ili protiv određenih javnih (i poreznih) politika“. ${ }^{72}$

Izbjegavanje stvaranja prostora arbitrarnog zakonodavnog tumačenja ustava posebno je naglašeno u suvremenosti, kada se države suočavaju s paradoksalnom tendencijama rasta veličine nacionalnih ekonomija te, usporedno, rasta dohodovnih i imovinskih nejednakosti. U tom kontekstu, primarnim ciljem socijalnih država postaje ostvarenje snažnije redistribucije dohotka i bogatstva u svrhu osiguranja socijalne sigurnosti te poticanja ekonomskih aktivnosti. ${ }^{73}$ Politički predstavnici, kao kreatori fiskalnih politika, pritom su suočeni s činjenicom „,nepopularnosti“ poreza te je u tom kontekstu moderne porezne sustave moguće okarakterizirati ,nelagodnim kompromisom između uzvišenih načela i političkog pragmatizma“ “ ${ }^{74}$ Stoga je nužna beskompromisna predanost ustavnim načelima poreznog sustava, interpretiranim u svjetlu temeljnih vrijednosti i socijalne opredijeljenosti cjeline ustavnoga teksta, u svrhu postavljanja jasnih granica fiskalnom suverenitetu zakonodavne vlasti, kako se legislativna diskrecija u pogledu financijskih pitanja ne bi pretvorila u političku samovolju. Uslijed apstraktnosti i promjenjivosti sadržaja načela pravednosti u oporezivanju, kreatori fiskalnih i poreznih politika nerijetko će intervencije u okviru poreznog sustava i/ili pojedinog poreznog oblika opravdavati upravo potrebom postizanja veće razine pravednosti. Jelčić ističe kako se pravednim poreznim sustavom može smatrati onaj koji je u određenom vremenu i sredini od većine građana ocijenjen i prihvaćen kao pravedan. ${ }^{75}$ Pritom interes građana za pravednom raspodjelom poreznog tereta $\mathrm{i}$ interes države u pogledu izdašnosti poreznih prihoda nisu nužno suprotstavljeni, već komplementarni. U tom smislu treba shvatiti moralni aspekt oporezivanja kao, s jedne strane, dužnost građana (poreznih obveznika) na snošenje pravednog udjela u financiranju javnih izdataka u skladu s gospodarskim

72 Kuzelj V., op. cit. u bilj. 68, str. 474.

73 Ihori T., Principles of Public Finance, Springer, Singapore, 2017., str. 3.

74 Samuelson P. A. i Nordhaus W. D., Economics, McGraw-Hill Irwin, New York, 2010., str. 313.

75 Jelčić Bo., Kakav novi porezni sustav?, Računovodstvo i financije, sv. 39, br. 6, 1993., str. 44. 
mogućnostima te, s druge strane spektra, obvezu države na uspostavu pravedne raspodjele poreznog tereta i racionalno trošenje poreznih prihoda. ${ }^{76}$

Druga sporna posljedica opisanog ustavnosudskog pristupa ogleda se u drastično smanjenoj mogućnosti pozivanja zakonodavca na odgovornost u slučaju propusta pri uređenju poreznog sustava. Ukoliko USRH ne nastupa adekvatno u razradi ustavnih principa, izbori su jedini preostali mehanizam odgovornosti. Građani, naime, nisu u mogućnosti posredstvom obvezujućih instrumenata neposredne demokracije utjecati izravno na porezni sustav ili pojedine njegove oblike. ${ }^{77}$ Imajući u vidu tako sužene mogućnosti političkog djelovanja na određivanje pravednosti poreza, potrebno je inzistirati na ustavnosudskom nadzoru ne bi li se izbjeglo poimanje svakog usvojenog poreza kao apriorno pravednog, čime bi se zajedno ,s poreznom državom urušila i socijalna država". ${ }^{78}$ Ovo je posebno bitno u hrvatskom kontekstu, u kojem proces uravnoteživanja poreznih načela i političkog pragmatizma počesto završava u korist potonjeg, jer ustavne se odredbe lakše smatra ,pogodnim sredstvima u političkoj borbi“79 nego protutežama većinske volje.

76 Perić R. i Konjić E., Primjena načela pravednosti u sustavima oporezivanja dohotka, u: Arbutina H. i Rogić Lugarić T. (ur.), Spomenica Prof. dr. sc. Juri Šimoviću, Pravni fakultet Sveučilišta u Zagrebu, Studijski centar za javnu upravu i javne financije, Zagreb, 2017., str. 42.; Perić R. i Jerković E., Principle of Fairness in Regard to Personal Income Tax, u: Bacher U. et al. (ur.), Interdisciplinary Management Research X, Josip Juraj Strossmayer University of Osijek, Faculty of Economics in Osijek, Postgraduate Studies „Management“, Hochschule Pforzheim University, Osijek, 2014., str. 828.; Jerković E., Advantages and Disadvantages of Models of Personal Income Taxation Concerning Employment Income and Independent Personal Services Income, u: Przygoda M.; Cingula, M. i Yongqiang, L. (ur.), Economic and Social Development, 24th International Scientific Conference on Economic and Social Development - „Managerial Issues in Modern Business“, Book of Proceedings, Varazdin Development and Entrepreneurship Agency, Faculty of Management University of Warsaw, University North, Warsaw, 2017., str. 84.

77 Smerdel upozorava na važnost realističnog i objektivnog tumačenja odredbe URH (čl. 87., st. 1.) prema kojoj se referendum može raspisati o pitanjima iz nadležnosti Hrvatskog sabora te navodi pitanja o kojima ne bi bilo moguće odlučivati na referendumu, ,,primjerice o ukidanju poreza“, Smerdel B., Ustavno uređenje europske Hrvatske, Narodne novine, Zagreb, 2013., str. 391.; isto Smerdel B., Neposredno odlučivanje i njegove ustavne granice, Hrvatska pravna revija, sv. 10, br. 11, 2010., str. 7. Barić ističe da, iako URH ne sadrži eksplicite enumerirane materije o kojima se ne može raspisati referendum, one su implicitne u ustavnoj državi te se tako o pitanjima poreza ne može odlučivati na referendumu, Barić S., O porezima se ne može raspisati referendum..., 24sata, 9. kolovoza 2017., https://www.24sata.hr/news/ sanja-baric-o-porezima-se-ne-moze-raspisati-referendum-535345 [pristup: 10. lipnja 2021.]. Za takvo je gledište moguće naći dva uporišta. Jedno je složenost porezne i proračunske materije koju ne moraju nužno razumjeti niti saborski zastupnici, a kamoli prosječan birač. Složenost je naravno i problem utoliko što je nemoguće neposrednim putem istovremeno odlučiti o jednom konkretnom pitanju i o načinu na koji će se ono odraziti na ostatak poreznog sustava te na proračun. Konačno, problem je i u tome što neposrednom demokracijom može biti teško osigurati ravnomjernu zastupljenost suprotstavljenih interesa, uslijed čega angažirana manjina može sebi u korist raspodijeliti ekonomske terete. Tu je bojazan izrazio i Ustavni sud Bavarske u svojoj odluci iz 2000. godine, vidi Odluka u predmetu Vf. 2-IX-00 od 31. ožujka 2000., str. 41.

78 Kuzelj V., op. cit. u bilj. 45, str. 102.

79 Smerdel B., Kriza demokratskog konstitucionalizma i izgledi demokratske tranzicije u Republici Hrvatskoj, Zbornik Pravnog fakulteta u Zagrebu, sv. 69, br. 1, 2019., str. 20. 


\section{SPOJIVOST IZRAŽENIJE ULOGE USTAVNOSUDSKOG TUMAČENJA SOCIJALNE DRŽAVE S INSTITUCIONALNOM ULOGOM SUDA}

Ukoliko se prate zahtjevi za ozbiljnijim angažiranjem argumenata iz socijalne države u ustavnom sudovanju, postoji opasnost od sudskog aktivizma. U takvom bi scenariju USRH svojim naglašenim djelovanjem mogao probiti granice svoje uloge i uzurpirati položaj zakonodavca. Ovdje valja ustvrditi kako to nije nužan ishod. Prije svega, valja imati u vidu da ograničenja uloge USRH ne slijede iz granica načela koja treba primijeniti, već iz njegovih institucionalnih ograničenja koja treba adekvatno argumentirati, a ne pozivanjem na amorfnu političnost socijalne države pružati neograničeni placet volji zakonodavca. Drugo, iako su ustavni sudovi u zenitu svojeg utjecaja kada iz pravnog poretka uklanjaju neustavne sadržaje, teorije takozvanog sudskog nadzora slabe forme pružaju ustavnim sudovima mogućnost da djeluju blaže i formativno, izbjegavajući agresivno oblikovanje javnih politika za koje nemaju legitimitet niti institucionalni prostor.

Važno je imati u vidu temelj sudskog aktivizma. Njega se može uglaviti u dvije osnove, pozivanjem na sadržaj koji se tumači ili pozivanjem na obilježja uloge aktera koji tumači taj sadržaj. U djelovanju USRH naspram poreza razvidan je prvi pristup. Primjerice, u odluci o kriznom porezu, USRH se pozvao dijelom na stranu judikaturu, a dijelom na vlastito načelno čitanje URH ne bi li utvrdio zakonodavčev primat pri tumačenju socio-ekonomskih kategorija temeljnog hrvatskog akta. ${ }^{80}$ Ovo je problematičan pristup utoliko što u načelima konstitucionalizma fiksira podjelu na ustavne odrednice koje su manje ili više političke te stoga manje ili više podložne ustavnom sudovanju. U konkretnom slučaju socijalne države, zakonodavac dobiva praktički apsolutnu slobodu „,konkretizacije“ ustavnih polazišta, iako iz njih samih po sebi takva sloboda ne mora slijediti. U ovakvom bi pristupu i najmanje snažnije inzistiranje USRH na socijalnoj državi moglo biti shvaćeno pretjeranim aktivizmom kojega se ne može dopustiti, čak i ukoliko sadržaj ustavnosudskog tumačenja ne ograničava u bitnome ovlasti predstavničkog tijela.

S druge pak strane, moguće je pratiti Rodina i tvrditi da USRH, kao niti druga ustavna sudišta, nije u mogućnosti uzimati u obzir politički suprotstavljene interese niti ima legitimitet potreban da bi o takvim srazovima odlučivao. ${ }^{81} \mathrm{U}$ slučaju da se sudski aktivizam ravna po tom mjerilu, ustavno sudovanje će moći slobodnije tumačiti temeljni akt, jer neće biti vezano granicama koje se pripisuje samoj materiji o kojoj se odlučuje. Ovo, međutim, od USRH traži dosljedno promišljanje vlastite institucionalne uloge u definiranju značenja odrednica URH te tumačenje koje se neće samo pozivati na strane uzore ili se zadržati na načelnim primjedbama o odlukama ustavotvorca. Takva vrsta interpretacije na polju nadzora poreznog

80 USRH je tako zauzeo stav da „uređenje i razradu“ „socijalne države“, „,socijalne pravde“ i „,socijalnih prava“ treba vršiti zakonodavno tijelo, USRH, Odluka i Rješenje U-IP-3820/2009 i U-IP3826/2009 i dr., od 17. studenoga 2009., para 13.1.

81 Rodin S., op. cit. u bilj. 1, str. 117. 
sustava još nije u značajnoj mjeri zapažena, usprkos tome što je njome moguće dugoročno izgraditi autonomnu i izraženu ulogu USRH, koji istovremeno neće presezati u pitanja za koja institucionalno nema kapaciteta.

Konačno, izneseno promišljanje adekvatne uloge USRH u bitnome je oblikovano ovlastima kojima raspolaže. Za to je tijelo moguće reći kako može djelovati neprimjereno svojoj ulozi stoga što ima ovlast utvrđivanja neustavnosti ishoda političkih procesa te, s time povezano, monološkog nametanja jednog značenja ustavnih odredbi. Upravo se, imajući u vidu strah od jednostranog blokiranja demokratski legitimiranih grana vlasti, može braniti odvojenost socijalne države od ostatka socio-ekonomske ustavne arhitekture te njezino minimalističko tumačenje. Zakonodavcu mora ostati ovlast „konkretizacije“ temeljnog akta.

Ovakvo je viđenje neispravno utoliko što zanemaruje dio ustavne teorije koja, razvijanjem sudskog nadzora slabe forme, otvara prostor djelovanju ustavnog sudišta kojim će se informativno djelovati na druge grane vlasti. Sudski nadzor slabe forme zapažen je u pojedinim jurisdikcijama upravo u pogledu zaštite socijalnih prava. ${ }^{82}$ Primjenom takve ustavnosudske ocjene ustavni sudovi ne uklanjaju određeni pravni sadržaj ili određeno tumačenje kao neustavno, već pružaju principijelno tumačenje temeljnog akta na koje je zakonodavno tijelo slobodno autonomno reagirati. Time se potiče konstruktivnu interakciju između različitih tijela vlasti i sprječava ustavnosudsku dominaciju u tumačenju.

U konačnici, USRH raspolaže mogućnošću da odredi drugi rok stupanja vlastite odluke na snagu ${ }^{83}$ te time odgodi učinke ukidanja poreznog zakona ${ }^{84}$ Time se omogućuje zakonodavcu da u vremenu do stupanja na snagu ukidne odluke izmijeni neustavne zakonske odredbe ili donese novi zakon, u skladu s iznesenim ustavnosudskim tumačenjem. ${ }^{85}$ Ovdje dolazi do izražaja uloga suvremenog ustavnoga sudstva, koja nadilazi tradicionalno učenje o ulozi ustavnih sudova kao tzv. „,negativnih zakonodavaca“, obilježenih načelom samoograničenja ili doktrinom o političkim pitanjima. Suvremena koncepcija ustavnog sudovanja dopunjena je ovlastima davanja smjernica zakonodavcu, kroz snagu pravne argumentacije, kako postupati pri budućem uređenju određene materije; te kroz tzv. interpretativne odluke kojima se, putem tumačenja odredbi zakona i propisa, osigurava buduća ustavnost njihove primjene. ${ }^{86}$ Naposljetku, ustavnom interpretacijom se uspostavljaju smjernice i mjerila za postupanje i djelovanje političkih grana vlasti upravo s ciljem

82 Vidi, primjerice, Tushnet M., Weak Courts, Strong Rights: Judicial Review and Social Welfare Rights in Comparative Constitutional Law, Princeton University Press, Princeton, 2008.; Dixon R., Creating dialogue about socioeconomic rights: Strong-form versus weak-form judicial review revisited, International Journal of Constitutional Law, sv. 5, br. 3, 2007., str. 391-418.

83 Ustavni zakon o Ustavnom sudu Republike Hrvatske, Narodne novine br. 99/99, 29/02, 49/02, čl. 55 , st. 2 .

84 Arlović M., Ustavnosudska kontrola poreznih zakona u Republici Hrvatskoj, u: Tadić M. (ur.), Porezno pravo i ustavno sudstvo, Ustavni sud Bosne i Hercegovine, Sarajevo, 2018., str. 109.

85 Ibid., str. 109.; Omejec J., Pravni učinci ustavnosudske kontrole zakona i drugih propisa, u: Crnić J. i Filipović N. (ur.), Ustav kao jamac načela pravne države, Organizator, Zagreb, 2002., str. 107.

86 Šarin D., Položaj Ustavnog suda Republike Hrvatske s motrišta diobe vlasti $i$ ustavne garancije njegove neovisnosti, Zbornik Pravnog fakulteta u Zagrebu, sv. 62, br. 5-6, 2012., str. 1393. 
pomirenja ustavnih aspiracija i zbiljskog života, ${ }^{87}$ a ne stvaranja pravnog i fiskalnog kaosa.

Prilikom ispitivanja materijalne ustavnosti zakonskih akata (napose poreznih), s mogućom posljedicom ukidanja zakona ili pojedinih njegovih odredbi, valja imati na umu kako takvo odlučivanje (bez obzira na snagu pravne argumentacije) u sebi nužno sadrži i određenu političku konotaciju. Stoga je potrebno konstantno balansiranje USRH između ustavnosudskog aktivizma i načela samoograničenja, temeljeno na suvremenoj koncepciji vladavine prava koja opravdava ograničenje suvereniteta parlamenta u svrhu zaštite i promicanja ljudskih prava i sloboda, kako bi se legislativna diskrecija zadržala unutar ustavnih granica. ${ }^{88}$ Izneseno je u skladu s poimanjem ustavnosudske uloge prema tzv. austrijskom modelu (kakav je prihvaćen i u RH), temeljenom na ideji supremacije ustava. ${ }^{89}$ Stoga, uvažavajući značajan spektar slobode zakonodavca pri uređenju fiskalne i porezne materije, ne treba $a$ prirori zaključiti kako ispitivanje suglasnosti fiskalnog i poreznog zakonodavstva sa stajališta načela poreznog sustava (čl. 51.), tumačenih u svjetlu temeljnog socijalnog opredjeljenja ustavnoga poretka (čl. 1., st. 1. i čl. 3.), predstavlja miješanje USRH u zakonodavnu nadležnost ili politička pitanja. Naprotiv, snagu argumenata ustavnosudskog tumačenja treba shvaćati kao poveznicu između ustavnog ideala i društvene stvarnosti, ${ }^{90} \mathrm{u}$ nastojanju da potonja u što je moguće većoj mjeri odražava temeljne vrednote društvene i državne zajednice. Naime, upravo je zadaća USRH „kao medijatora društvenih zbivanja usmjeravati cjelokupni pravni poredak prema temeljnim vrednotama i načelima koja su sadržana u samom Ustavu“ .91

\section{ZAKLJUČAK}

Nema spora da Ustavni sud definira socijalnu državu. Problem je u tome što je počesto definira svojim odsustvom, što se isto tako treba smatrati djelovanjem koje ustavna teorija mora problematizirati. Ovdje je to učinjeno kroz usmjerenost na temeljni ustavnosudski manevar u Republici Hrvatskoj, a to je izdvajanje socijalne države u iznimno stvorenje, poprilično agnostički nastrojeno prema izborima zakonodavca. Opravdano je tvrditi da taj konstitucionalistički agnosticizam svoj problematičan izričaj nalazi u poreznom sustavu, ali i da on nije „sudbina“ hrvatske

87 Omejec J., Novi europski tranzicijski ustavi i transformativna uloga ustavnih sudova, u: Bačić A. (ur.), Dvadeseta obljetnica Ustava Republike Hrvatske, Hrvatska akademija znanosti i umjetnosti, Zagreb, 2011., str. 80 .

${ }_{88}$ Sokol S., Ustavni sud Republike Hrvatske u zaštiti i promicanju vladavine prava, u: Crnić J. i Filipović N. (ur.), Ustav kao jamac načela pravne države, Organizator, Zagreb, 2002., str. 16-17.

89 Omejec J., op. cit. u bilj. 83, str. 97.

90 Jelušić M., Razvoj uloge i djelovanja Ustavnog suda Republike Hrvatske od donošenja Ustava 1990. do danas, u: Bačić A. (ur.), Ustavne promjene i političke nagodbe: Republika Hrvatska između ustavne demokracije i populizma, Hrvatska akademija znanosti i umjetnosti, Zagreb, 2021., str. 306.

91 Šeparović M., Novi izazovi pred Ustavnim sudom RH: Ustavni sud kao zaštitnik temeljnih ustavnih vrijednosti $i$ medijator društvenih zbivanja, u: Bačić A. (ur.), Ustavne promjene i političke nagodbe: Republika Hrvatska između ustavne demokracije i populizma, Hrvatska akademija znanosti i umjetnosti, Zagreb, 2021., str. 299. 
socijalne države. Temeljni akt Republike Hrvatske svakako sadrži načela i odredbe kojima je moguće na odgovornost pozvati zakonodavca kada uređuje porezni sustav i pojedine njegove oblike. Takvo pozivanje ne mora biti suprotno ulozi USRH, ukoliko ovaj adekvatno argumentira svoje mjesto u hrvatskom ustavnom poretku te mudro iskoristi spektar ovlasti koje mu stoje na raspolaganju.

Valja primijetiti kako u sferi gospodarskih i socijalnih prava (osobito u pogledu fiskalnog i poreznog zakonodavstva) suzdržanost USRH prije ukazuje na dobrovoljnu pasivnost prema političkim granama vlasti (poglavito zakonodavnoj), nego na doktrinarnu suzdržanost prema izboru ekonomskih i socijalnih politika kao implikaciju koncepcije ekonomske neutralnosti URH ili na dosljednost u primjeni načela ustavnosudskog samoograničenja i doktrine o političkim pitanjima. Stoga je potrebno pledirati za zauzimanje aktivnijeg stava USRH u zaštiti socijalnih prava građana (poreznih obveznika).

Izloženo zauzimanje za kreativnije i principijelnije djelovanje USRH u konačnici može biti samo to, plediranje. O samome USRH ovisi kakav će stav zauzeti u društveno-političkom kontekstu koji utječe na njegovu odluku. Sigurno je samo da, iako su ekonomske doktrine prolazne i promjenjive, a ustavne vrijednosti načelno trajne i otporne na promjene, ovaj odnos može lako postati obratan, čineći ustave beznačajnima i ekonomska poimanja stamenima, ukoliko se ne osvijesti da značenja koja se trenutno pripisuju socijalnoj državi nisu jedine moguće opcije.

\section{REALIZATION AND PROTECTION OF TAX EQUITY AS A CONSTITUTIONAL IDEAL IN LIGHT OF THE REQUESTS OF THE SOCIAL STATE}

This paper reconsiders the accepted simplified and un-questioned differentiation between the constitutional concept of the social state, social rights, and the tax system. It finds it practical effect in the agency of The Constitutional Court of the Republic of Croatia which, due to the gap between these categories, fails to adequately interpret and protect the concept of the social state in reviewing the constitutionality of tax legislation. The absolute result is a space of an excessive constitutional self-restraint. Contrary to the fear of judicial activism, which is presented as the single alternative to the continuous invocation of the political questions doctrine, it is emphasized that the social state should be interpreted as a pervasive guideline for the interpretation of the tax system in order to achieve the significance it contains as a component of the Croatian constitutional identity. The link between the social state and more specific tax categories does not necessarily lead to a politically hyperactive Court, as long as it focuses mainly on the weakness and consequences of its decisionmaking mode when defining the limits of its own action, instead of insisting on the limitations of interpreted principles.

Key words: social state, social rights, constitutional principles of taxation, tax equity, The Constitutional Court of the Republic of Croatia 